\title{
Effects of intra-articular corticosteroids in vivo on synovial fluid variables in rheumatoid synovitis
}

\author{
E. J. Goetzl, N. E. Bianco, J. S. Alpert, C. B. Sledge, and P. H. SCHUR \\ From the Departments of Medicine and Surgery, Harvard Medical School, \\ and the Robert Bent Brigham Hospital, Boston, Mass.
}

Intra-articular instillation of corticosteroids in patients with rheumatoid arthritis (RA) is often followed by transient relief of symptoms and signs of local synovitis (Hollander, Brown, Jessar, and Brown, 1951; Ziff, Scull, Ford, McEwen, and Bunim, 1952). The basis for this clinical improvement is not known and has not been comprehensively correlated with changes in the characteristic synovial fluid (SF) abnormalities of RA. Decreases in the SF acid phosphatase level and leucocyte count (Ziff and others, 1952; Lemperg, Beckman, and Beckman, 1971) and transient decreases in SF haemolytic complement $\left(\mathrm{CH}_{50}\right)$ level (Hunder and McDuffie, 1972) have been reported after the intra-articular administration of a corticosteroid. The theoretical bases for these alterations include the ability of corticoids to suppress immune inflammation in vivo (Gell, 1955), to inhibit leucocyte chemotaxis (Ward, 1966) and other leucocyte functions (Packer and Greendyke, 1960) in vitro, and to stabilize leucocyte and other cell lysosomal membranes (Weissmann and Dingle, 1961). We therefore investigated the concomitants of the beneficial clinical effect of intraarticular corticosteroids in patients with RA, using serial SF leucocyte counts and acid phosphatase levels as a measure of inflammation. SF rheumatoid factor (RF) titres and complement levels were determined to assess local immune abnormalities.

\section{Material and methods}

PATIENT POPULATION

Twelve patients with the diagnosis of definite or classical RA (Ropes, Bennett, Cobb, Jacox, and Jessar, 1959) were studied. At the time of the study the patients had active disease (Lansbury, 1966) and, based on the results of the serum latex-fixation test for RF (Singer and Plotz, 1956), were designated eit.her RF $(+)$ or RF $(-)$. The twelve patients included nine RF (+) and three RF (-).

\section{PROCEDURE}

SF samples were collected before and 4 to 30 days (mean 15) after the intra-articular administration of $40 \mathrm{mg}$. methylprednisolone (Depo-Medrol, Upjohn Co.). In addition, for three of the patients, SF samples were obtained from the opposite knee into which saline instead of corticosteroid was administered. Local clinical abnormalities were assessed just before each knee aspiration and were assigned a composite grade based on a system with seven separately scored components:

Duration of knee morning stiffness ( $0-3$ points),

Knee pain (0-3),

Loss of walking ability (0-3),

Local inflammation $(0-1)$,

Knee effusion (0-1),

Knee limitation of motion (0-1)

Radiological damage (0-3).

The scores for all components were added to arrive at the knee composite grade which could have a maximum of 15 points.

Each SF sample was analysed for total leucocyte count and differential, total protein, glucose, and mucin clot formation (Ropes and Bauer, 1953). Immunological studies included total haemolytic complement, $\mathrm{CH}_{50}$ (Kent and Fife, 1963) (normal serum has a range of 150 to 250 units $/ \mathrm{ml}$.), C4 protein level (Ruddy, Carpenter, Müller-Eberhard, and Austen, 1968) (normal serum values of 211-633 mg./ml.), and RF titres. SF complement levels are approximately one-third of the corresponding serum concentration in patients with osteoarthritis (Britton, Ruddy, Corson, Sosman, Schur, and Austen, 1972). SF acid phosphatase levels were measured by the method of Andersch and Szczypinski with $p$-nitrophenylphosphate (Sigma Chemical Co.) as the substrate (Andersch and Szczypinski, 1947).

\section{Results}

SF CH5O AND C4 LEVELS AND RF TITRES Levels of $\mathrm{CH}_{50}$ and $\mathrm{C} 4$ protein and RF titres are shown in Table I. Pre-treatment $\mathrm{CH}_{50}$ and $\mathrm{C} 4$ levels 
Table I Effect of intra-articular corticosteroid on complement levels and rheumatoid factor titres in synovial fluid

\begin{tabular}{|c|c|c|c|c|c|c|c|c|}
\hline \multirow{2}{*}{\multicolumn{2}{|c|}{$\begin{array}{l}\text { Intra- } \\
\text { articular } \\
\text { injection }\end{array}$}} & \multirow{3}{*}{$\begin{array}{l}\begin{array}{l}\text { Number of } \\
\text { patients }\end{array} \\
9 \\
3\end{array}$} & \multicolumn{2}{|c|}{ Mean $\mathrm{CH}_{50}$ (units/ml.) } & \multicolumn{2}{|c|}{ Mean $C 4(\mu g . / m l)}$. & \multicolumn{2}{|c|}{ Mean RF titre } \\
\hline & & & Before & After & Before & After & Before & After \\
\hline Corticoid & $\begin{array}{l}\text { RF (+) } \\
\text { RF (-) }\end{array}$ & & $\begin{array}{l}23 \\
58\end{array}$ & $\begin{array}{l}29 \\
42\end{array}$ & $\begin{array}{r}57 \\
267\end{array}$ & $\begin{array}{r}53 \\
116\end{array}$ & $\begin{array}{l}1: 1,280 \\
0\end{array}$ & $\begin{array}{l}1: 1,280 \\
0\end{array}$ \\
\hline line & $\begin{array}{l}\mathrm{RF}(+) \\
\mathrm{RF}(-)\end{array}$ & $\begin{array}{l}2 \\
1\end{array}$ & $\begin{array}{l}38 \\
36\end{array}$ & $\begin{array}{l}30 \\
26\end{array}$ & $\begin{array}{r}70 \\
145\end{array}$ & $\begin{array}{r}39 \\
125\end{array}$ & $\begin{array}{l}1: 2,560 \\
0\end{array}$ & $\begin{array}{l}1: 2,560 \\
0\end{array}$ \\
\hline
\end{tabular}

Values shown are mean levels, before and after injection, of total haemolytic complement $\left(\mathrm{CH}_{50}\right)$ and protein concentration of the fourth component of complement (C4). The mean titre of rheumatoid factor was that value in a series of two-fold dilutions of an originally ten-fold diluted sample which was closest to the calculated mean. Each saline-injected knee was always contralateral to a corticoid-injected knee.

are comparable to those previously reported by this laboratory in RA (Ruddy, Britton, Schur, and Austen, 1969). In six out of twelve knees which received intra-articular methylprednisolone, no alterations were observed in $\mathrm{CH}_{50}, \mathrm{C} 4$ protein levels, or $\mathrm{RF}$ titres. The other six patients showed a fall in only one of the above three SF values. A fall of at least 50 per cent. in $\mathrm{C} 4$ protein level was observed in SF from two corticoid-treated knees and also in SF from one saline-injected joint. The $\mathrm{C} 4$ level in SF showed an equivalent rise in one corticoid-treated knee. The $\mathrm{CH}_{50}$ level rose at least 100 per cent. in SF from corticoid-treated knees of two other patients and the SF rheumatoid factor titre rose two tubes in a sixth corticoid-treated patient.

\section{SF LEUCOCYTE COUNTS AND ACID PHOSPHA- TASE LEVELS}

SF leucocyte counts, percentage of polymorphonuclear leucocytes, and levels of acid phosphatase before and after intra-articular administration of corticosteroids or saline are presented in Table II. A decrease in the number of SF leucocytes and the percentage of SF polymorphonuclear leucocytes was observed after the intra-articular administration of either saline or corticosteroid in eleven of the thirteen instances where paired values are available; one patient (8) had a rise in the percentage of SF polymorphonuclear leucocytes and another (11), a rise in the leucocyte count after corticoid injection.

A decrease of at least 40 per cent. was observed in the levels of SF acid phosphatase in ten of the fourteen patients who had paired determinations (Table II). SF acid phosphatase from both knees of one patient (12) rose with clinical exacerbation, but the level in the corticoid-injected knee rose less than in the saline injected knee.

\section{CLINICAL RESPONSE}

All but one patient (12), experienced alleviation of local symptoms and showed a fall in the knee clinical grade after the intra-articular administration of corticosteroids which persisted to the time of reaspiration of SF (Table II). This residual clinical improvement was moderate ( 3 or more points) in five patients and mild ( 2 or fewer points) in six patients injected with corticoid. The clinical responses did not correlate quantitatively with either SF

Table II Effect on synovial fluid variables of intra-articular corticosteroids

\begin{tabular}{|c|c|c|c|c|c|c|c|c|c|}
\hline \multirow{2}{*}{$\begin{array}{l}\text { Patient } \\
\text { no. }\end{array}$} & \multirow[t]{2}{*}{ Diagnosis } & \multicolumn{4}{|l|}{ Before corticoid } & \multicolumn{4}{|l|}{ After corticoid } \\
\hline & & $\begin{array}{l}\text { Leucocyte count } \\
\text { (number/mm. }{ }^{3} \text { ) }\end{array}$ & $\begin{array}{l}\text { Per cent. } \\
\text { Polys }\end{array}$ & $\begin{array}{l}\text { Acid phosphatase } \\
\text { (mg./ml./hr) }\end{array}$ & $\begin{array}{l}\text { Clinical } \\
\text { grade }\end{array}$ & $\begin{array}{l}\text { Leucocyte count } \\
\text { (number/mm. }{ }^{3} \text { ) }\end{array}$ & $\begin{array}{l}\text { Per cent. } \\
\text { Polys }\end{array}$ & $\begin{array}{l}\text { Acid phosphatase } \\
\text { ( } \mathrm{mg} . / \mathrm{ml} . / \mathrm{hr})\end{array}$ & $\begin{array}{l}\text { Clinical } \\
\text { grade }\end{array}$ \\
\hline \multirow[t]{2}{*}{$\begin{array}{r}1 \\
2 \\
3 \\
4 \\
5 \\
6 \\
7 \\
8 \\
9 \\
10 \\
11 \\
12\end{array}$} & $\begin{array}{l}\mathbf{R F}(+) \\
\mathbf{R F}(+) \\
\mathbf{R F}(+) \\
\mathbf{R F}(+) \\
\mathbf{R F}(+) \\
\mathbf{R F}(+) \\
\mathbf{R F}(+) \\
\mathbf{R F}(+) \\
\mathbf{R F}(+) \\
\mathbf{R F}(-) \\
\mathbf{R F}(-) \\
\mathbf{R F}(-)\end{array}$ & $\begin{array}{r}14,200 \\
88,000 \\
\text { N.D. } \\
7,300 \\
12,300 \\
4,600 \\
3,700 \\
4,400 \\
10,200 \\
8,200 \\
6,200 \\
7,960\end{array}$ & $\begin{array}{l}75 \\
80 \\
\text { N.D. } \\
\text { N.D. } \\
90 \\
7 \\
90 \\
65 \\
78 \\
81 \\
78 \\
81\end{array}$ & $\begin{array}{l}3.8 \\
5.07 \\
7.9 \\
5.6 \\
5.6 \\
0.51 \\
1.6 \\
1.8 \\
2.08 \\
0.83 \\
0.81 \\
0.76\end{array}$ & $\begin{array}{r}7 \\
11 \\
6 \\
10 \\
7 \\
8 \\
10 \\
8 \\
14 \\
6 \\
9 \\
2\end{array}$ & $\begin{array}{r}2,000 \\
40,000 \\
\text { N.D. } \\
1,600 \\
4,600 \\
\text { N.D. } \\
430 \\
492 \\
2,500 \\
7,600 \\
6,600 \\
2,100\end{array}$ & $\begin{array}{l}5 \\
18 \\
\text { N.D. } \\
\text { N.D. } \\
14 \\
\text { N.D. } \\
24 \\
72 \\
33 \\
68 \\
46 \\
46\end{array}$ & $\begin{array}{l}0 \cdot 83 \\
2 \cdot 3 \\
2.2 \\
1 \cdot 1 \\
1 \cdot 0 \\
0 \cdot 50 \\
0 \cdot 34 \\
0 \cdot 62 \\
0 \cdot 77 \\
\text { N.D. } \\
0.55 \\
1 \cdot 2\end{array}$ & $\begin{array}{r}5 \\
7 \\
4 \\
7 \\
6 \\
4 \\
8 \\
6 \\
10 \\
4 \\
6 \\
6\end{array}$ \\
\hline & & \multicolumn{4}{|l|}{ Before saline } & \multicolumn{4}{|l|}{ After saline } \\
\hline $\begin{array}{r}8 \\
9 \\
12\end{array}$ & $\begin{array}{l}\mathbf{R F}(+) \\
\mathbf{R F}(+) \\
\mathbf{R F}(-)\end{array}$ & $\begin{array}{r}1,300 \\
700 \\
4,400\end{array}$ & $\begin{array}{r}5 \\
44 \\
78\end{array}$ & $\begin{array}{l}0.18 \\
1.6 \\
0.62\end{array}$ & $\begin{array}{r}9 \\
14 \\
3\end{array}$ & $\begin{array}{r}700 \\
160 \\
3,800\end{array}$ & $\begin{array}{r}2 \\
18 \\
68\end{array}$ & $\begin{array}{l}0.10 \\
0.69 \\
3.7\end{array}$ & $\begin{array}{r}7 \\
10 \\
6\end{array}$ \\
\hline
\end{tabular}

Each saline-injected knee was always contralateral to a corticoid-injected knee. 
leucocyte or acid phosphatase levels. In one patient (12), a worsening of the local clinical findings occurred and correlated with increases in levels of SF acid phosphatase as noted. To illustrate the temporal association between the changes in clinical and SF findings, we present the following case report:

Case 1 is a 55-year-old female patient with a diagnosis of classical RA of 7 years' duration involving the feet, ankles, hands, wrists, and knees. She has subcutaneous nodules and a positive serum latex test $(1: 10240)$. Antinuclear antibodies and LE cell test were negative. On May 20,1971 she had an acute flare-up of synovitis in the left knee. SF was obtained and analysed and $40 \mathrm{mg}$. methylprednisolone was administered intra-articularly with relief over the ensuing 24 hours. On June 2, 1971 (13 days later), a second SF sample was obtained. At this time she had no local symptoms, minimal effusion, and increased range of motion, and she did well until July 23, 1971 (60 days after the intra-articular administration of corticoids) when she had a second flare-up in the left knee. SF was again obtained and analysed, and at this time no intra-articular corticosteroid was given. Despite receiving high-dose salicylates, intramuscular gold, and intensive physical therapy, she showed little improvement. On October 26, 1971, she experienced a further exacerbation of the synovitis in her left knee. After a SF sample had been obtained, she was again given $40 \mathrm{mg}$. intraarticular methylprednisolone, and there was a noticeable improvement 24 hours later. When she was last seen in the clinic on December 10,1971, she was improved with a quiescent left knee.

Data from these SF studies are shown in Table III. The clinical grades are most closely paralleled by the SF leucocyte values and acid phosphatase levels.

\section{Discussion}

It has been known for almost 20 years that the intraarticular administration of corticosteroids in patients with RA is generally accompanied by transient local relief of symptoms and signs (Hollander and others, 1951; Ziff and others, 1952). Whether this action of corticoids is due simply to their potent antiinflammatory properties or to a local immunosuppressive action remains uncertain. In this study, synovial fluid samples were examined for levels of total haemolytic complement and $\mathrm{C} 4$ protein, titres of RF, and concentrations of acid phosphatase before and after the intra-articular administration of methylprednisolone. In three patients, the same measurements were made in the contralateral knee which did not receive corticosteroids. Improvement of local symptoms with decrease in swelling and effusion, disappearance of stiffness and increase in motion were seen within 24 hours after the intraarticular injection in eleven of twelve patients and persisted to the time of repeat synovial fluid aspiration (Table II). The local clinical improvement was associated with a marked decrease in SF acid phosphatase level, SF leucocyte count, and percentage of polymorphonuclear leucocytes in most of the patients. SF total haemolytic complement, C4 protein level, and titre of RF were unchanged in 50 per cent. of the corticoid-treated patients and only one of these variables was altered in the other six patients. The fact that similar changes were observed in two out of three patients when SF was obtained from the contralateral saline-injected knee suggests either a systemic effect of the corticoid or an effect attributable to the process of aspiration and intra-articular injection alone.

The local anti-inflammatory action of intraarticular corticoids has previously been reported. Ziff and others (1952) reported that patients who had intra-articular hydrocortisone showed local relief of symptoms, decrease in SF levels of aminotripeptidase, and diminished total SF leucocyte count, associated with a remission of symptoms lasting from 8 days to 3 months. Lemperg and others (1971) noted that the intra-articular injection of hydrocortisone was followed by a significant drop in SF acid phosphatase levels in patients with RA. The lowering of the SF levels of acid phosphatase in patients with RA after intra-articular steroids may represent an in vivo counterpart of the observations of Weissmann and Dingle (1961) on the lysosomal membrane stabilizing effect of corticosteroids.

Hunder and McDuffie (1972) reported that intraarticular administration of hydrocortisone to patients with either RA, 'chronic indeterminate polyarthritis' of the knee and ankles, or arthritis associated with regional enteritis resulted in decreases in the synovial fluid titres of whole complement and the levels of $\mathrm{C} 3$ and $\mathrm{C} 4$ protein which correlated with a decrease in

Table III Serial determinations of synovial fluid variables after a dose of intra-articular corticoid in one patient (No. 1 in Table II)

\begin{tabular}{|c|c|c|c|c|c|c|c|}
\hline Date & $\begin{array}{l}\text { Clinical } \\
\text { grade }\end{array}$ & $\begin{array}{l}\mathrm{CH}_{50} \\
\text { (units/ml.) }\end{array}$ & $\begin{array}{l}C 4 \\
(m g . / m l .)\end{array}$ & $\begin{array}{l}R F \\
\text { (titres) }\end{array}$ & $\begin{array}{l}\text { Total } \\
W B C\end{array}$ & $\begin{array}{l}\text { Percent. } \\
\text { Polys }\end{array}$ & $\begin{array}{l}\text { Acid phosphatase } \\
\text { (mg./ml./hr) }\end{array}$ \\
\hline $\begin{array}{l}20 \text { May '71* } \\
2 \text { June ' } 71 \\
23 \text { July ' } 71 \\
26 \text { Oct. ' } 71 \text { * }\end{array}$ & $\begin{array}{l}7 \\
5 \\
7 \\
9\end{array}$ & $\begin{array}{l}26 \\
20 \\
32 \\
38\end{array}$ & $\begin{array}{l}68 \\
54 \\
68 \\
85\end{array}$ & $\begin{array}{l}1: 5,120 \\
1: 5,120 \\
1: 5,120 \\
1: 5,120\end{array}$ & $\begin{array}{r}14,200 \\
2,000 \\
11,750 \\
16,000\end{array}$ & $\begin{array}{l}75 \\
5 \\
\text { N.D. D. } \\
85\end{array}$ & $\begin{array}{l}3 \cdot 8 \\
0 \cdot 83 \\
4 \cdot 17 \\
6 \cdot 95\end{array}$ \\
\hline
\end{tabular}

* 40 mg. methylprednisone given by intra-articular injection. 
SF leucocyte count and amelioration of symptoms. These effects were transient with maximal changes from 12 to 24 hours after injection. In this study we did not measure complement levels within the 24 hours after administering intra-articular methylprednisolone and would have missed an early transient depression.

Increasing amounts of experimental evidence have indicated that immunological changes may be important in mediating the inflammatory changes of rheumatoid synovitis. The exaggerated synthesis of immunoglobulins by the rheumatoid synovium (Herman, Bradley, Ziff, and Smiley, 1971), the elevated levels of SF anti-gamma globulin in patients with RA (Weissmann, Zurier, Spieler, and Goldstein, 1971), the depressed levels of complement (Ruddy and others, 1969), and the release of lysosomal enzymes from SF leucocytes which are phagocytosing IgG-anti IgG complexes (Allison, Smith, and Wood, 1955) suggest that immunological events may play a significant role in the inflammatory changes seen in rheumatoid synovitis. Neither SF complement levels nor RF titres were affected at the time of persistent clinical improvement after corticosteroids and therefore local immunosuppression has not been demonstrated. The mechanism of corticoid reduction of SF leucocyte counts and, in particular, of polymorphonuclear leucocytes, may be related in part to the known corticoid suppression of leucocyte chemotaxis. In vitro studies have suggested that steroids will diminish the infiltration of inflammatory cells into areas of injury by a direct effect on leucocyte motility (Ward, 1966; Ward, Cochrane, and MüllerEberhard, 1965). The low levels of complement and complement components found in SF from patients with RA may be the reflection of activation by IgG-RF complexes (Britton and others, 1972) of the complement sequence which can generate chemotactic factors for leucocytes (Ward and Hill, 1970). In addition, neutral proteases from WBC lysosomes have been found to generate chemotactic activity from C3 (Taubman, Goldschmidt, and Lepow, 1970) and C5 (Ward and Hill, 1970). These observations may help to explain both the usual accumulation of polymorphonuclear leucocytes in rheumatoid SF and the suppressive effect of corticoids. At the present time, it is not clear if intraarticular corticoid instillation interferes with the immune generation of chemotactic factors or simply suppresses leucocyte chemotactic response to the factors. This study suggests that transient local relief of signs and symptoms in RA synovitis after intraarticular administration of steroids may be related to blocking vectors of inflammation without altering the immunological process seen in this disease.

\section{Summary}

Synovial fluid from knee joints of twelve patients with rheumatoid arthritis were analysed before and 4 to 30 days after an intra-articular injection of methylprednisolone. After corticoid injection, clinical improvement was moderate in five patients and mild in six; one had an exacerbation in local disease. Six of the patients showed no alteration in synovial fluid $\mathrm{CH}_{50}, \mathrm{C} 4$ protein level, or rheumatoid factor titre and the other six demonstrated a 50 per cent. of greater change in only one of these synovial fluid values. All but one of the ten patients with paired ceff counts showed a decrease in the total synovial fluid leucocyte count and the percentage of polymorphonuclear leucocytes and all but three patients had a 40 per cent. or greater fall in synovial fluid acid phosphatase concentration following the corticoid injection. The data suggest that the transient improvement in clinical symptoms and signs which follows the intra-articular administration of corticosteroids is related to their anti-inflammatory action reflected in decreases in synovial fluid leucocyte counts and lysosomal enzyme levels without any alteration of the basic immune aberrations characteristic of rheumatoid synovitis.

\section{References}

Allison, F., Smith, M. R., AND Wood, W. B. (1955) J. exp. Med., 102, 669 (Studies on the pathogenesis of acute inflammation. Action of cortisone on the inflammatory response to thermal injury)

Andersch, M. A., ANd Szczypinski, A. J. (1947) Amer. J. clin. Path., 17, 571 (Use of P-nitrophenylphosphate as the substrate in determination of serum acid phosphatase)

Britton, M. C., Ruddy, S., Corson, J. M., Sosman, J. L., Schur, P. H., and Austen, K. F. (1972) In 'Immune reactions and experimental models in rheumatic diseases: Proc. IV Canad. Conf. on Research in Rheum. Dis., Oct. 15-17, 1970', ed. D. A. Gordon, p. 40. University Press, Toronto. (The complement system in rheumatoid synovitis. III. The relationship of synovial fluid complement levels to the clinical, radiological and pathological changes in rheumatoid arthritis)

Gell, P. G. H. (1955) Int. Arch. Allergy, 6, 326 (Histology of allergic lesions in rabbits and the effect of cortisone)

Herman, J. H., Bradley, J., Ziff, M., and Smiley, J. D. (1971) J. clin. Invest., 50, 266 (Response of the rheumatoid synovial membrane to exogenous immunization)

Hollander, J. L., Brown, E. M., Jessar, R. A., AND Brown, C. Y. (1951) J. Amer. med. Ass., 147, 1629 (Hydrocortisone and cortisone injected into arthritic joints: comparative effect of and use of hydrocortisone as a local antiarthritic agent) 
HuNDER, G. G., AND MCDUfFIE, F. C. (1972) J. Lab. clin. Med., 79, 62 (Effect of intra-articular hydrocortisone on complement in synovial fluid)

Kent, J. F., AND Fife, E. H. (1963) Amer. J. trop. Med., 12, 103 (Precise standardization of reagents for complement fixation)

LANSBURY, J. (1966) 'Methods for evaluating rheumatoid arthritis', In 'Arthritis and Allied Conditions', 7th ed., ed. J. L. Hollander, p. 276. Lea and Febiger, Philadelphia, Penn.

Lemperg, R. K., Beckman, G. N. M., ANd Beckman, L. E. A. (1971) Acta rheum. scand., 17, 195 (Effect of intraarticular corticosteroid administration on acid and alkaline phosphatase activity in synovial fluid of patients with rheumatoid arthritis)

Packer, J. T., AND Greendyke, R. M. (1960) Trans. Ass. Amer. Phys., 73, 93 (The inhibition of erythrophagocytosis in vitro by corticosteroids)

Ropes, M. W., AND BAUER, W. (1953) 'Synovial Fluid Changes in Joint Disease'. Harvard University Press, Cambridge, Mass.

—, Bennett, G. A., Cobb, S., Jacox, R., and Jessar, R. A. (1959) Ann. rheum. Dis., 18, 49 (Revision of diagnostic criteria for rheumatoid arthritis)

Ruddy, S., Britton, M. C., Schur, P. H., and Austen, K. F. (1969) Ann. N.Y. Acad. Sci., 168, 161 (Complement components in synovial fluid: activation and fixation in seropositive rheumatoid arthritis)

-, CARPenter, C. B., Müller-Eberhard, H. J., and Austen, K. F. (1968) 'Complement component levels in hereditary angioneurotic edema and isolated $\mathrm{C}_{2}{ }_{2}$ deficiency in man', in 'Immunopathology: $\mathrm{V}$ int. Symp., 167: Mechanisms of Inflammation induced by Immune Reactions', ed. P. A. Miescher and P. Grabar, p. 231. Schabe, Basel

Singer, J. M., AND Plotz, C. M. (1956) Amer. J. Med., 21, 888 (The latex fixation test. I. Application to the serologic diagnosis of rheumatoid arthritis)

Taubman, S. B., Goldschmidt, P. R., and Lepow, I. H. (1970) Fed. Proc., 29, 434 (Effects of lysosomal enzymes from human leukocytes on human complement components)

WARD, P. A. (1966) J. exp. Med., 124, 209 (The chemosuppression of chemotaxis)

- Cochrane, C. G., AND Müller-Eberhard, H. J. (1965) Ibid., 122, 327 (The role of serum complement in chemotaxis of leukocytes in vitro)

- AND Hill, J. H. (1970) J. Immunol., 104, 535 (C5 chemotactic fragments produced by an enzyme in lysomal granules of neutrophils)

Weissmann, G., AND Dingle, J. (1961) Exp. Cell Res., 25, 207 (Release of lysosomal protease by ultraviolet irradiation and inhibition by hydrocortisone)

-, Zurier, R. B., SPIELER, P. J., AND GoldSTEIN, I. M. (1971) J. exp. Med., 134, 149S (Mechanism of lysosomal enzyme release from leukocytes exposed to immune complexes and other particles)

Ziff, M., Scull, E., Ford, D., McEwen, C., AND Bưnim, J. J. (1952) Arch. intern. Med., 90, 774 (Effects in rheumatoid arthritis of hydrocortisone and cortisone injected intra-articularly) 